\title{
Double Development Cycle of Trypanosoma Cruzi in the Opossum
}

\author{
M.P. Deane, H. L. Lenzi and A.M. Jansen
}

Opossums are important wild reservoirs of Trypanosoma cruzi, and by their frequent entry into houses can form a link between sylvatic and domestic cycles of Chagas disease transmission. The finding of a developmental cycle of $T$. cruzi in the anal glands of opossums therefore has epidemiological as well as biological significance.

$T$. cruzi was found to grow abundantly as epimastigotes and to transform into trypomastigotes identical to metacyclic forms, in the lumen of the anal glands of a high proportion of laboratory reared opossums (Didelphis marsupialis) that had been subcutaneously inoculated with faeces of infected triatomine bugs. No intracellular amastigotes were found in the various layers of the gland wall, not even in the thick striated muscular layer. The developmental phases in the lumen of the anal glands appear to mimic the parasite's developmental cycle in the intestinal tract of the insect vectors (Figs I and 2). At the same time, a classic intracellular cycle, with trypomastigotes in the bloodstream, was shown by patent parasitaemia, positive haemoculture and xenodiagnosis, and by finding amastigotes in myofibres of several muscles. All the opossums were positive in indirect fluorescent antibody tests. Parasites taken directly from the anal glands were cultivated in axenic media, infected triatomine bugs, mice and opossums, and were typed to the same schizodeme and zymodeme of those derived from the blood and those of the inoculated strain. No doubt, the population that developed in the lumen of the anal glands was part of

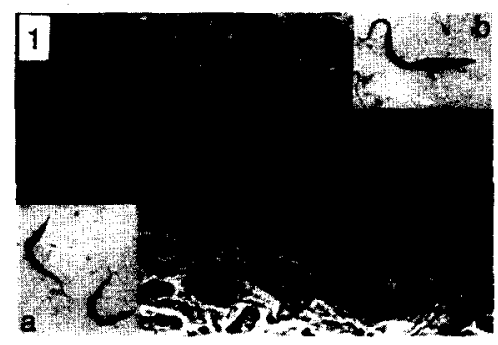

Fig. 1. Giemsa-stained preparations of the contents of the anal gland of one opossum infected with T. cruzi, showing a mass of parosites, chiefly epimostigotes. Insets: smear of same material showing (a) two trypomastigotes, and (b) one epimastigote. (a) and (b) from Ref. 4.

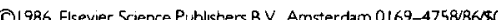

the population inoculated and circulating in the tissues ${ }^{1-5}$

The anal glands of opossums appear to be involved in a defence reaction; they are present in both sexes and produce material with an offensive odour which is ejected when the opossum is attacked or irritated. The glands are paired and communicate through a narrow duct with the lumen of the rectum very near the anal opening ( $F i g$. 3). Their contents are rich in neutral lipids and hyaluronic acid' ${ }^{6}$ and usually seem to be bacteriologically sterile, despite the rich rectal flora (C.A. Solari. unpublished)

T. cruzi epimastigotes in the glands are full of lipid inclusions!. There is no attachment to the epithelial cells of the gland wall, as has been described for these parasites in the rectum of their insect vectors 7.8

\section{Epidemiological Implications}

The family Didelphidae is one of the most widely distributed mammalian groups in the Western Hemisphere? ${ }^{9}$. All three species, Didelphis azarae (= abiventris), $D$. marsupialis and $D$. virginiana have been found naturally infected with $T$. cruzi. Due to their ample distribution, which spreads beyond the limits of the endemic areas of human trypanosomiasis and to their high rates of natural infection, these marsupials are one of the most important wild reservoirs of Chagas disease. They are also incriminated as links between sylvatic and domestic transmission cycles, because of their omnivorous foraging habits, that frequently bring them into contact with human dwellings in rural and suburban areas 10.11 .

Transmission of Chagas disease is normally maintained by domestic species of blood-sucking triatomine bugs. However, limited epidemics of acute human cases (with several deaths) have been reported outside the endemic areas and in the absence of domestic species of Triatominae. Investigation of two of these epidemics led to the conclusion that infections had been simultancous and by the oral route, but the source remained obscure. In both cases opossums were suspected of being involved, either directly by contaminating food with their urine, or indirectly, through a sylvatic triatomine bug flying into the house and contaminating food with its faeces, ( $T$. cruzi strains isolated from the human patients and from opossums captured in the neighbourhood belonged to the same zymodeme ${ }^{(2-15}$ ). Our discovery of the cycle of $T$. cruzi in the anal glands of opossums supports the idea of direct involvement of this animal, without necessarily involving the insect vectors. In the laboratory we could infect mice by feeding them on a mixture of breadcrumbs moistened with milk and the material squeezed from the glands of an infected opossum; the mixture was infective for at least $24 h^{16}$.

Even in endemic areas, infection of man by the oral route is probably more frequent than usually supposed, and according to some authors, should be suspected whenever an acute patient does not show the typical inflammatory reaction at the initial site of infection 12 . Contamination of food or the oral mucosa by triatomine faeces is thought to be the most probable mechanism, but opossums could also be directly involved by contamination of food with anal gland secretions.

Among other mammals, ingestion of infected Triatominae, or meat and viscera of infected animals, is undoubtedly a very important means of acquiring $T$. cruzi infection. This is particularly so for the omnivorous opossums ${ }^{17}$. Many sylvatic. domestic or semi-domestic species of Triatominae have been associated with opossums, either found in opossum nests or with opossum blood in their guts ${ }^{10}$, but vector transmission does not easily explain the high rates of infection in opossums in areas where triatomine bugs are scarce ${ }^{18}$.

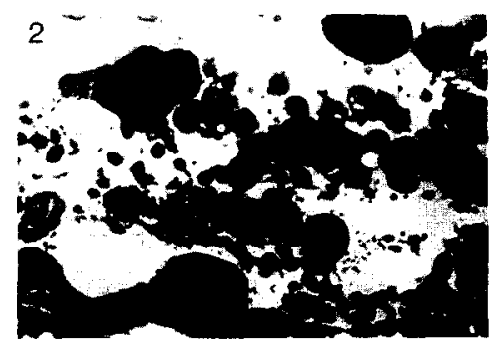

Fig. 2. Epon-embedded semi-thin section showing parasites in the interior of the anal gland amidst secreted moterial and cells scaled off the inner glandular epithelial layer. 


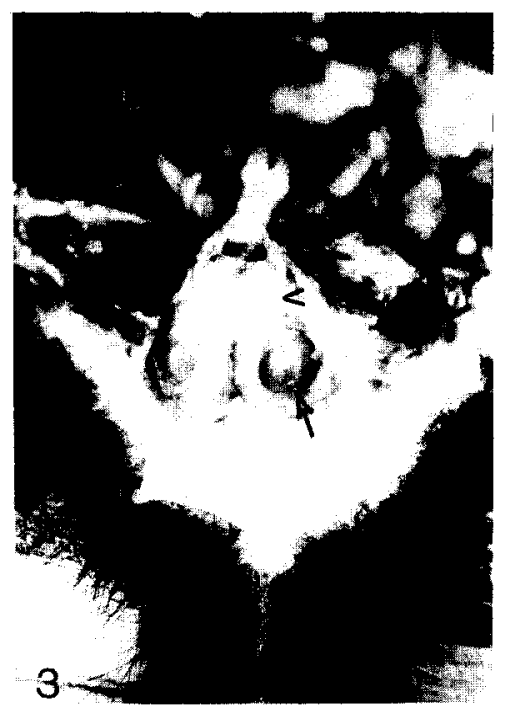

Fig. 3. The anal glands (arrow) in schiopubic region; the ducts (arrow-head) drain to the anus. The glans penis is bifid. (From Ref. 4.)

In our experience with almost 200 closely watched opossums we had no evidence of direct transmission of $T$, cruzi infection, despite the presence of the parasite in the anal glands of a number of them. However, our animals are normally maintained in individual cages, except during lactation and copulation, and it appears that tame specimens seem to forget the defence reaction which culminates with ejection of the anal gland secretion.

\section{Biological Questions}

Inside the opossum's anal glands T. cruzi obviously finds whatever it needs for nutrition and transformation, and is protected against the immune defences of the host. Could the intra-luminal situation be a sufficient explanation for this protection?

The influence of temperature in triggering transformation of digenetic trypanosomatids is well known. $T$. cruzi strains differ in the thermosensitivity of the amastigote-trypomastigote transformation in vitro and, in a study of $T$. cruzi in embryonated chicken eggs, the parasite underwent a double cycle in eggs incubated at $32-34^{\circ} \mathrm{C}$, while only the intracellular cycle was found in eggs maintained at $37.5-39^{\circ} \mathrm{C}^{19-21}$.

The average body temperature of opossums is lower than that of eutherian mammals, the rectal average in our specimens being $32.6^{\circ} \mathrm{C}$ (M.F. Dezonne, unpublished) and varying from 30.2 to $32.9^{\circ} \mathrm{C}$ for $D$. azarae 22 . So far, only those strains of $T$. cruzi originating from naturally infected opossums have developed in the anal glands of our inoculated animals. It may be that body temperature is one of the factors responsible for the double cycle of $T$. cruzi in the opossum, and this may lead to opossums exerting a selective effect on particular strains of the parasite ${ }^{23}$.

\section{Acknowledgements:}

Our work received grants from CNPq. Brazil and from the WHO Special Programme.

\section{References}

I Deane, M.P., Lenzi, I I.L. and Jansen, A.M. (1984) Mem Inst. Oswaldo Cruz 79, 513-515

2 Carreira, J.C.A. et al. XII Reunicio Anual sobre Pesquisa Básica em Doença de Chagos. Caxambu, MG, Brazil, 5-7 November, 1985, p. 50

3 Thomaz, N. et al. XI Reuniōo Anual sobre Pesquiso Básica em Doença de Chagas. Ca×ambu, MG, Brazil, 20-22 November, 1984, p. 46

4 Lenzi. H.J., Jansen, A.M. and Deane, M.P. (1984) Mem. Inst. Oswaldo Cruz (Suppl.) 79, 13-18

5 Lenzi, H.L., Carreira, J.C.A. and Deane, M.P. XII Reuniāo Anual sobre Pesquisa Básica em Doença de Chagas. Caxambu, MG, Brazil, 5-7 November, 1985, p. 50

6 Olivera, M.M. et al. XII Reuniōo Anual sobre Pesquisa Bósica em Doença de Chagas. Caxambu. MG, Brazil, 5-7 November, 1985, p. 91

7 Böcker, C.A. and Schaub, G.A. (1984) Z. für Parasiten kd. 70, 459-469

8 Zeledón, R, Bolaños, R. and Rojas, M. (1984) Acto Trop. 4I, 39-43

9 Hunsaker, D. (1971) in The Biology of Marsupicis (Humsaker, D. ed.) pp. 95-156. Academic Press, New York

\section{LETTERS}

\section{Is Tryponosoma brucei an intracellular parasite?}

Sir - It has been known for half a century that suramin will only cure infections with Tryponosoma brucei if treatment is given in the early stages of the disease. The greater the delay in treatment, the more likely is a relapse of the infection.

Several groups ${ }^{1-3}$ have shown that trypanosomes can be found in the tissues of the brain and its appendages. However, the significance of this finding only became apparent when Jennings et al. ${ }^{4}$ showed that suramin could clear trypanosomes from all tissues of the body except those of the brain, indicating that the relapse of infection would most likely originate from parasites in the brain rather than from other parts of the body. Protection of the trypanosomes from suramin by the 'blood/brain barrier' appeared to many to be a satisfactory explanation of this phenomenon, despite the earlier finding by Keevill ${ }^{5}$ that suramin could penetrate this barrier and clear trypanosomes from the cerebrospinal fluid.

Abolarin and colleagues ${ }^{6}$ have published electron micrographs of ependymal cells in the choroid plexus which demonstrate the possibility that these specialized cells may harbour the
10 Barretto. M.P. (1979) in Trypanosoma cruzi e Doença de Chagas (Brener, Z and Andrade, Z. eds) pp. 89-151, Guanabara Koogan S.A., Rio de Janeiro

Zeledón, R et al (1970) j. Porositol. 56, 38

12 Guimaräes. F.N et al (1968) O Hospitol 73, 73110

13 Shaw, J, Lainson, R and Frahia, H. (1969) Rev Saude Púb. São Paulo 3, 153-157

14 Lainson, R. Shaw. I.). and Naiff, RD. (1980) Rev. inst. Med. Irop. São Poulo 22, 294-297

15 Miles, M.A. et al (1978) Nature (London) 272. 819-821

16 Jansen, A.M. and Deane, M.P. XII Reuniōo Anuol sobre Pesquisa Básica em Doença de Chogas. Caxambu. MG, Brazil. 5-7 November, 1985, p. 39

17 Carreira, I.C.A. et al. $\times$ Reuniōo Anuol sobre Pesquiso Básico em Doença de Chagas. Caxambu MG, Brazil, 8-10 November, 1983, pp 3-10

18 Mckeever, S., Gormon, G.W. and Norman, L. (1958)J. Parasitol. 44. 583-587

19 Neva, F.A., Malone, M.F. and Myers, B.R. (1961) Am. J. Trop. Med Hyg 10, 140-154

20 Brener, Z, et al (1976)J Protozool 23, 147-150

21 Mello. M.N. and Deane, M.P. (1976) Ann. Trop. Med. Parasitol. 70, 381-388

22 Godinho, H.P., Cardoso. F.M. and Noguelra, J.C. (1977) Acto Anotomico 99, 204-208

23 Thomaz, N. et al. XII Reuniōo Anual sobre Pesquisa Básica em Doença de Chogos. Caxambu. MG Brazil, 5-7 November, 1985, p.40

Maria Deone and Ana Jansen are in the Department of Protozoology ond Henrique Lerzi is in Ule Department of Pathology, Oswaldo Cruz institute, Av. Brasil 4365-2 1040 Rio de Janeiro RJ., Brazil.

trypanosomes in an intracellular form. The same group, at the 23rd International Congress of Protozoology, demonstrated further 'intracellular trypomastigotes' in the ependymal cells of the choroid plexus (Fig. I) and also in the same cell type which forms the lining of the ventricles of the brain.

Critics of this work have raised several objections. Firstly they have pointed out that trypomastigotes are such long organisms that it would take about a thousand serial microsections to display a whole individual, and that a few such sections could hardly demonstrate that the whole trypomastigote was inside an ependymal cell - a part of it could just be poking into the host cell and the rest remaining extracellular. Secondly the critics emphasize the state of

degeneration of the affected cells and the rarity with which convincing 'intracellular' trypanosomes are seen within them; they argue that if the same amount of time had been spent in looking at other parts of the brain as had been devoted to those that contain ependymal cells, the same appearances of intruding trypomastigotes and degenerating cells might have been found at other sites. Finally it has been shown that apparendly intracellular trypomastigotes can also be found in tissues outside the brain, mainly in plasma cells ${ }^{7}$. In evaluating this apparently serious objection one has to remember that the 